Extremity/Lymphedema Image

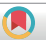

\section{Heterotopic ossification} arising from an anterolateral thigh free flap donor site: a previously unreported phenomenon

Fergal Marlborough, Juan Enrique Berner, Daniel Bernard Saleh, Maniram Ragbir

Department of Plastic Surgery, The Newcastle upon Tyne Hospitals NHS Foundation Trust, Newcastle upon Tyne, UK

Correspondence: Juan Enrique Berner

Department of Plastic Surgery, The Newcastle upon Tyne Hospitals NHS Foundation Trust, Royal Victoria Infirmary, Queen Victoria Rd, Newcastle upon Tyne, NE1 4LP, UK

Tel: +44-191-233-6161, Fax: +44-191-233-6161, E-mail: juan.berner@nhs.net

Received: November 22, 2020 • Revised: January 6, 2021 •

Accepted: January 23, 2021

pISSN: 2234-6163 • elSSN: 2234-6171

https://doi.org/10.5999/aps.2020.02355 • Arch Plast Surg 2021;48:547-548 Copyright (c) 2021 The Korean Society of Plastic and Reconstructive Surgeons This is an Open Access article distributed under the terms of the Creative Commons Attribution Non-Commercial License (https://creativecommons.org/licenses/by-nc/4.0/) Attribution Non-Commercial License (https:///creativecommons.org/licenses/by-nc/4.0/
which permits unrestricted non-commercial use, distribution, and reproduction in any medium, provided the original work is properly cited.

Heterotopic ossification is defined as abnormal bone deposition within non-skeletal tissues. Although it is rare, it has been associated with a history of trauma and surgical interventions. Herein, we present the case of a 74-year-old male patient, who was referred to our specialist center with a high-grade myxofibrosarcoma affecting his left knee. After a multidisciplinary discussion, wide resection and reconstruction with a contralateral free anterolateral thigh (ALT) free flap were performed. A $25 \times 12 \mathrm{~cm}$ flap was harvested and its donor site repaired using a split-thickness skin graft, followed by adjuvant radiotherapy.

Over the course of 9 months following radiotherapy, the patient slowly developed a painless swelling on his right thigh. On examination, he presented a hard, raised mass measuring $12 \times 5 \mathrm{~cm}$ under the healed split-thickness skin graft on the ALT donor site (Fig. 1). The mass did not affect his mobility. Plain X-ray films (Fig. 2A) and a computed tomography scan (Fig. 2B) were obtained and evaluated by senior radiologists with experience in

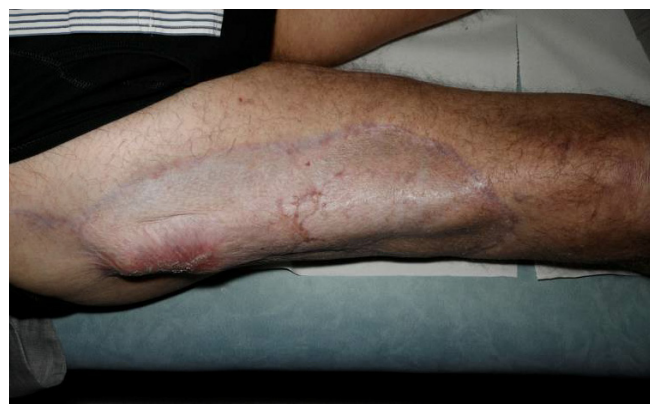

Fig. 1.

Firm swelling at the proximal anterolateral thigh donor site.
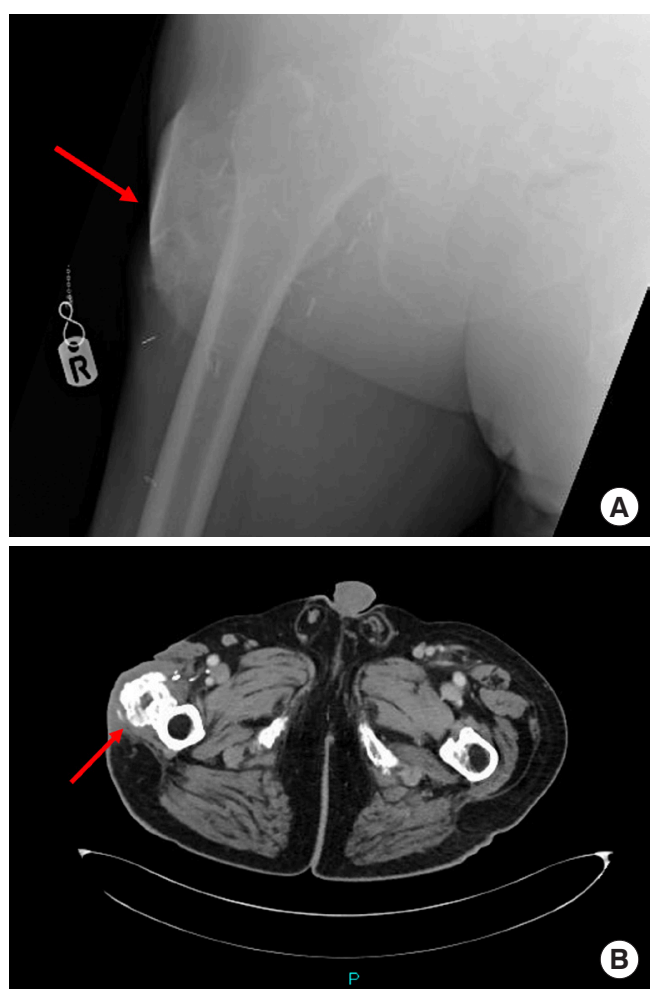

Fig. 2.

Heterotopic ossification (red arrow) at the right thigh anterolateral thigh donor site. (A) Plain X-ray film. (B) Computed tomography scan. sarcoma surgery, who agreed that the findings were consistent with heterotopic ossification and that histological confirmation was not required. The patient was reassured, and no further surgical intervention was sought.

Heterotopic ossification of free fibula flap pedicles has been previously reported and thought to be related to periosteum retained along the pedicle [1]. Studies have also described the development of heterotopic ossification within the rectus sheath following the harvest of a free rectus abdominis flap for limb reconstruction [2], as well as within a temporalis flap for ear reconstruction [3]. To the best of our knowledge, heterotopic ossification arising at an ALT donor site has not been previously reported and we do not have an explanation for this phenomenon. 
Notes

\section{Conflict of interest}

No potential conflict of interest relevant to this article was reported.

\section{Ethical approval}

As per the United Kingdom Health Research Authority guidelines, case reports do not require institutional review board approval. Written informed consent was obtained.

\section{Patient consent}

The patient provided written informed consent for the publication and the use of his images.

\section{Author contribution}

Conceptualization: F Marlborough, JE Berner, DB Saleh, M Ragbir. Data curation: F Marlborough. Methodology: JE Berner. Project administration: F Marlborough. Writing - original draft: F
Marlborough, JE Berner, M Ragbir. Writing - review

\& editing: JE Berner, DB Saleh, M Ragbir.

\section{ORCID}

Juan Enrique Berner

https://orcid.org/0000-0003-2178-5161

Daniel Bernard Saleh

https://orcid.org/0000-0003-4849-6933

\section{References}

1. Autelitano L, Colletti G, Bazzacchi R, et al. Ossification of vascular pedicle in fibular free flaps: a report of four cases. Int J Oral Maxillofac Surg 2008;37:669-71.

2. Warr RP, Fitton AR, Dickson WA, et al. Ossification in the rectus sheath following free rectus flap. Br J Plast Surg 1999;52:663-4.

3. Price GJ, Stewart KJ. Heterotopic ossification of a temporal fascial flap pedicle in ear reconstruction. J Plast Reconstr Aesthet Surg 2010;63:e146-7. 